\title{
Prevalence of cataract in adult Down's syndrome patients
}

\author{
Basant K Puri ${ }^{*}$, lqbal Singh ${ }^{2}$ \\ From $1^{\text {st }}$ International Congress on Neurobiology and Clinical Psychopharmacology \\ and European Psychiatric Association Conference on Treatment Guidance \\ Thessaloniki, Greece. 19-22 November 2009
}

\section{Background}

Age-related cataract is the major cause of blindness in humans throughout the world. The majority of previous studies of cataract in Down's syndrome have reported a prevalence that is higher for a given age range than in the general population. The aim was to study the prevalence of cataract in a well-defined population of adults with Down's syndrome.

\section{Materials and methods}

An in-patient population of 68 adults (35 males and 33 females) with Down's syndrome, aged between 28.9 and 83.3 years, underwent ophthalmological examination for the presence of cataracts.

\section{Results}

Overall, the prevalence of cataract was $16.2 \%$, with no significant difference between males $(17.1 \%)$ and females (15.2\%). In those aged between 45 and 64 years, the prevalence was $16.7 \%$, rising in those aged between 65 and 75 years to $28.6 \%$.

\section{Conclusions}

Compared with the general population, the prevalence of cataract in Down's syndrome was raised in those aged 45 to 64, but not in those aged 65 to 75 years; the latter might be a function of the relatively small number of patients in this age group. The increased prevalence of cataract found in those in the 45- to 64-year-old age group may be the result of increased levels of CuZnSOD, in turn resulting from the location of the associated five exons of SOD1 on chromosome 21. These elevated levels of superoxide dismutase may give rise to increased levels of reactive species, including hydrogen

\footnotetext{
${ }^{1}$ Imaging Sciences Department, Hammersmith Hospital, Imperial College
} London, UK peroxide and hydroxyl radicals, which may increase the risk of cataractogenesis.

\section{Author details}

${ }^{1}$ Imaging Sciences Department, Hammersmith Hospital, Imperial College London, UK. ${ }^{2}$ Mental Health Unit, Hillingdon Hospital, Uxbridge, Middlesex, UK.

Published: 22 April 2010

\section{doi:10.1186/1744-859X-9-S1-S152}

Cite this article as: Puri and Singh: Prevalence of cataract in adult Down's syndrome patients. Annals of General Psychiatry 2010 9(Suppl 1): S152.
Submit your next manuscript to BioMed Central and take full advantage of:

- Convenient online submission

- Thorough peer review

- No space constraints or color figure charges

- Immediate publication on acceptance

- Inclusion in PubMed, CAS, Scopus and Google Scholar

- Research which is freely available for redistribution

Submit your manuscript at www.biomedcentral.com/submit 